\title{
Temperature, thermal comfort, and animal ingestion behavior in a silvopastoral system
}

\section{Temperatura, conforto térmico e comportamento ingestivo animal em sistema silvipastoril}

\author{
Nilson Aparecido Vieira Junior ${ }^{1 *}$; Marcelo Augusto de Aguiar e Silva ${ }^{2}$; \\ Paulo Henrique Caramori ${ }^{3}$; Pablo Ricardo Nitsche ${ }^{3}$; Karlmer Abel Bueno Corrêa \\ Daniel Soares Alves ${ }^{3}$
}

\begin{abstract}
Thermal discomfort is one of the main causes of production losses in animals fully exposed to solar radiation under extensive livestock farming. The inclusion of trees in this farming system is the most efficient strategy to decrease the temperature and increase animal productivity without the need to explore new areas. In this context, the objective of this study was to characterize the microclimate in a silvopastoral system (SPS), a refuge area, and an open pasture, and evaluate thermal comfort and the ingestive behavior of animals under shade. The study was conducted at the Agronomic Institute of Paraná (IAPAR), located in Ibiporã, Paraná state, Brazil, in three areas with distinct management systems: a SPS of Eucalyptus grandis with Tifton 85 (Cynodon spp.), a woodland of Leucena leucocephala that provided shade to cattle, and a pasture in full sun (PFS). Automatic meteorological stations were installed in the SPS (one station beside the tree lines and the other in an average distance perpendicular to the rows), one in the refuge area, and one in the PFS. The measured variables were air temperature and relative humidity. The mean temperatures of the shaded treatments were compared to those of the PFS using a $t$-test. The mean values of the temperature and humidity index (THI) were calculated for each season of the year. The animal ingestion behavior in the SPS was analyzed in three typical days in different seasons of the year. Significant differences were observed between shade treatments and full-sun pasture, with a temperature decrease ranging from 0.4 to $1.6^{\circ} \mathrm{C}$ in the shaded systems. The comparison of animal thermal comfort between the study areas in different seasons of the year indicated that there were no significant differences in thermal comfort between the SPS and refuge area relative to the PFS, suggesting a need to monitor the animals' body temperature to better estimate thermal comfort. The evaluation of the ingestive behavior evidenced the animals' preference to perform activities under tree shade and that the SPS led to changes in their food habits, optimizing grazing time. Therefore, the trees directly affected the microclimate of the studied environments, attenuating the temperature, protecting the animals against direct solar radiation, and providing better thermal comfort.
\end{abstract}

Key words: Area of refuge. Forest-livestock. Microclimate. Shade. Temperature and Humidity Index.

1 Discente, Curso de Doutorado, Programa de Pós-Graduação em Engenharia de Sistemas Agrícolas, Universidade de São Paulo, Escola Superior de Agricultura "Luiz de Queiroz", USP/ESALQ, Piracicaba, SP, Brasil. E-mail: nilsonvieirajunior@usp.br

2 Prof. Dr., Departamento de Agronomia, Universidade Estadual de Londrina, UEL/CCA, Londrina, PR, Brasil. E-mail: aguiaresilva@uel.br

3 Pesquisadores, Instituto Agronômigo do Paraná, IAPAR, Área de Ecofisiologia, Londrina, PR, Brasil. E-mail: pcaramori@gmail. com; pablonitsche@gmail.com; danielsoares31@yahoo.com.br

4 Discente, Curso de Mestrado, Programa de Pós-Graduação em Engenharia de Sistemas Agrícolas, USP/ESALQ, Piracicaba, SP, Brasil. E-mail: karlmerabc@usp.br

* Author for correspondence 


\section{Resumo}

O desconforto térmico é uma das principais causas da queda produtiva da pecuária extensiva a pleno sol, sendo a inserção de árvores no sistema a alternativa mais eficiente para atenuar a temperatura e aumentar a produtividade sem a necessidade de explorar novas áreas. Nesse contexto, objetivou-se caracterizar o microclima em um sistema silvipastoril, uma área de refúgio e a pleno sol, além de estimar o conforto térmico e avaliar o comportamento ingestivo dos animais sob sombra. $\mathrm{O}$ estudo foi realizado na estação experimental do Instituto Agronômico do Paraná (IAPAR), localizada em Ibiporã-PR, em três áreas com manejos distintos: um sistema silvipastoril, um bosque que serve como refúgio dos animais e uma pastagem a pleno sol. Foram instaladas estações meteorológicas automáticas no sistema silvipastoril, uma sob a sombra e outra na distância média perpendicular aos renques, na área de refúgio e no pasto a pleno sol. As variáveis medidas foram temperatura do ar e umidade relativa do ar. As temperaturas médias dos tratamentos arborizados foram comparadas com as do pasto a pleno sol por meio do test $t$. Valores médios de Temperatura e Índice de Umidade (ITU) foram calculados para cada estação do ano. Analisou-se o comportamento ingestivo animal no sistema silvipastoril em três dias representativos de diferentes estações do ano. Constatou-se diferenças significativas entre os tratamentos sombreados e a pastagem a pleno sol, com redução de temperatura variando entre 0,4 a $1,6^{\circ} \mathrm{C}$ nos sistemas sombreados. Ao comparar o conforto térmico animal para as estações do ano, não verificou-se diferenças entre o sistema silvipastoril e refúgio em relação ao pleno sol, sendo indicado monitorar a temperatura corporal animal para melhor estimar sua condição de conforto térmico. Entretanto, ao avaliar o comportamento ingestivo animal evidenciou-se a preferência dos animais por realizar suas atividades sob a sombra das árvores; o sistema silvipastoril propiciou mudanças no seu hábito alimentar, otimizando o tempo de pastejo. Conclui-se que o componente arbóreo influenciou diretamente no microclima dos ambientes estudados, atenuando a temperatura e protegendo os animais contra a incidência direta de radiação solar, proporcionando maior conforto térmico.

Palavras-chave: Área de refúgio. Índice de Temperatura e Umidade. Microclima. Pecuária-floresta. Sombreamento.

\section{Introduction}

Projections indicate that the world population will reach 9.3 billion people by 2050 (UNITED NATIONS, 2014), and that population growth is linked to food demand, which will increase by approximately $60 \%$ (FAO, 2016). At present, meat production worldwide corresponds to 288 million tons, and the increase in population will require the production of approximately 463 million tons of meat by the livestock sector (FAO, 2016).

Brazil has the largest commercial herd worldwide (IBGE, 2010), oscillating as the world's first or second largest producer of beef (JANK et al., 2014). Currently, the Brazilian livestock is based predominantly on pastures exposed to full sun, with an area of 200 million hectares, corresponding to approximately $23 \%$ of the national territory (CEPAL, 2017; FAO, 2010). This type of management degrades pasture and soil by intensive exploitation, with little or no concern about pasture management and maintenance. It is estimated that approximately $85 \%$ of the pasture area in the Brazilian territory is completely degraded or at some stage of degradation (IBGE, 2016).

Agricultural areas, including pastures, need to be improved to meet the growing demand for food, requiring more sustainable production (STRASSBURG et al., 2014). Livestock in tropical countries is highly influenced by thermal stress, which prevents the animal from expressing its productive potential (MOURA et al., 2010). The meteorological elements with the greatest effect on animal thermal comfort are air temperature, relative air humidity, and solar radiation that directly reaches the animals, and these factors cause physiological and behavioral changes in the animals to regulate their body temperature (SOUZA et al., 2010). 
Considering that climate is one of the main factors affecting animal production (SOUZA et al., 2010), tree systems are used to reduce the burden caused by high temperatures and increase livestock productivity in tropical regions. Silvopastoral systems (SPSs), which integrate tree species in pastures, are efficient in recovering degraded pastures, increasing the sustainability of the productive chain, and increasing income by combining animal and wood production (FREITAS et al., 2011).

The microclimatic changes generated by including trees in the system are important because animals with better thermal comfort need to spend less time in grazing and spend less energy in the search and ingestion of forage. Moreover, there is a choice of shaded areas in SPSs for rumination and rest, even for animals considered tolerant to high temperatures, such as beef cattle from tropical regions (DOMICIANO et al., 2016). Consequently, these systems improve energy use and decrease the stress caused by high temperatures. Therefore, the energy otherwise spent in regulating body temperature may be used to convert food into meat or milk, increasing productivity (CRUZ et al., 2011). In this context, the objective of the present study was to characterize the microclimate of a SPS and a refuge area, to determine the thermal comfort, evaluate the ingestive behavior of the animals under shade, and compare these two systems with a pasture in full sun (PFS) in the four seasons of the year.

\section{Material and Methods}

The present study was carried out at the Agronomic Institute of Paraná (IAPAR) experimental station located in the municipality of Ibiporã (latitude, $23.16^{\circ} \mathrm{S}$; longitude, $51.01^{\circ} \mathrm{W}$; altitude, $484 \mathrm{~m}$ ), Paraná, Brazil. The region's climate is subtropical humid (Cfa) according to Köppen's classification, with hot summers and undefined dry season (IAPAR, 2009). The soil is classified as Red Nitosol (EMBRAPA, 2013).
The assessments were carried in three areas with distinct types of management:

1) A SPS of eucalyptus (Eucalyptus grandis) with Tifton 85 (Cynodon spp.) in an area of 1.6 ha. The trees were 7 years old and were planted initially in rows $60 \mathrm{~m}$ long and spaced $15 \mathrm{~m}$ apart. Upon reaching the age of 4 years, the trees were thinned to reduce the length of the rows to $30 \mathrm{~m}$ and increase the spacing between rows to $30 \mathrm{~m}$.

2) A 0.17-ha Leucaena leucocephala woodland not affected by anthropic activities since 1991 and that provided shade to cattle during the hottest periods of the day.

3) A 7-ha Brachiaria brizantha grazing area in full sun.

Two meteorological stations were installed in each management system at a height of $1.70 \mathrm{~m}$. These stations were composed of a meteorological shelter housing sensors of air temperature $\left({ }^{\circ} \mathrm{C}\right)$ and relative humidity (\%), and a hermetically sealed compartment with electronic components for data collection and storage (GUEDES, 2013). In the SPS, one station was located under the tree canopy (SP shade), and the other was in full sun in the middle of the perpendicular distance between rows (SP full sun). In the shaded area (SA) and PFS, the mean values of the data collected in the two stations were calculated. Data were collected every 3 seconds, and the mean values were stored every 5 minutes. The data were collected during one week for each month from March 2017 to January 2018.

The data collected between 8:00 a.m. and 5:00 p.m. were used to select the hottest period of the day. The temperature data collected each month were grouped according to the seasons of the year, and the SPS and RA were compared with the PFS using a $t$-test with independent sampling at a level of significance of $5 \%$.

The temperature and humidity index (THI) was calculated from the meteorological data measured in the SPS, SA, and PFS to estimate the thermal 
comfort in each season. The THI is determined by measuring air temperature, relative air humidity, wet bulb temperature, or dew point temperature (MARTELLO et al., 2004). The THI can be expressed by the equation

$$
\mathrm{THI}=\mathrm{Ts}+0.36 \mathrm{Tpo}+41.5
$$

Where

THI is the temperature and humidity index (dimensionless);

Ts is the temperature of the dry bulb or air thermometer $\left({ }^{\circ} \mathrm{C}\right)$;

Tpo is the dew point temperature $\left({ }^{\circ} \mathrm{C}\right)$.

The temperature of the dew point (Tpo) was calculated using the Magnus equation:

$$
\begin{aligned}
\gamma(T, U R) & =\ln \left(\frac{U R}{100} \exp \left(\frac{b T}{c+T}\right)\right)=\ln \left(\frac{U R}{100}\right)+\frac{b T}{c+T} \\
T_{p o} & =\frac{c \gamma(T, U R)}{b-\gamma(T, U R)}
\end{aligned}
$$

Where

$\Upsilon$ is the psychrometric constant; $\mathrm{b}=17.67 ; \mathrm{c}=$ 234.5 .

According to the classification proposed by Zimbelman and Collier (2011) for dairy cattle, THI values $\leq 71$ indicate normal environmental conditions, i.e., without stress. Values between 72 and 79 indicate thermal discomfort (mild to moderate stress). THI values from 80 to 89 indicate moderate to severe stress, in which animals may suffer damage from high thermal discomfort. Furthermore, values higher than 90 are classified as severe stress, characterizing an emergency situation, which may cause death. This classification was used to estimated the levels of thermal comfort in the SPS and PFS in the four seasons of the year. The THI data for each treatment were grouped by season, and the shaded treatments were compared with the PFS using the $t$-test with independent sampling at the level of significance of $5 \%$.

For the analysis of animal ingestion behavior, 15 non-lactating cows of the Dutch breed aged approximately 40 months were used in the SPS. The cows were randomly distributed, and each animal constituted one repetition. According to the methodology proposed by Jamieson and Hodgson (1979), the evaluated factors were grazing time, rumination time, idling time, displacement time, and animal preference to perform these activities under shade or in full sun. Annotations were made every 10 minutes from 8:00 a.m. to 5:00 p.m., with three field trips during the year to characterize animal behaviors in different microclimatic conditions.

\section{Results and Discussion}

The inclusion of trees altered the microclimate of the studied systems because of the interception of solar radiation by the tree canopy. There were significant differences in temperature between the treatments during the seasons (Table 1). In autumn, the average air temperature was lower in the SP shade and SA relative to the PFS, with values of $1.6{ }^{\circ} \mathrm{C}$ and $0.4{ }^{\circ} \mathrm{C}$ lower in the SP shade and SA, respectively. In winter, the mean temperatures in these two treatments were $0.4{ }^{\circ} \mathrm{C}$ lower than those in the PFS. In the spring and summer, the mean air temperature in the SA was lower than that in the PFS, with a difference of $0.7^{\circ} \mathrm{C}$ and $0.9^{\circ} \mathrm{C}$, respectively. The similarity in mean temperatures between the SPS and PFS may be because of the change in solar declination, so that the sun rays were parallel to the tree rows for most of the day in these seasons, with higher incidence of solar radiation from the area closest to the trees to the central area of the spacing between the trees. 
Table 1. Comparison of the mean air temperature ( $t$-test) of the silvopastoral system between rows (SP full sun), under the tree shade (SP shade), and a shaded area (SA) relative to the pasture in full sun (PFS) in Ibiporã, state of Paraná, Brazil, in different seasons of 2017 and 2018.

\begin{tabular}{ccccccccc}
\hline \multirow{2}{*}{ Treatment } & \multicolumn{2}{c}{ Autumn } & \multicolumn{2}{c}{ Winter } & \multicolumn{2}{c}{ Spring } & \multicolumn{2}{c}{ Summer } \\
\cline { 2 - 8 } & Mean & STD $^{\mathbf{1}}$ & Mean & STD & Mean & STD & Mean & STD \\
\hline SP full sun & $20.3^{\text {ns }}$ & 4.30 & $17.4^{\text {ns }}$ & 3.03 & $27.4^{\text {ns }}$ & 4.30 & $28.8^{\text {ns }}$ & 2.90 \\
SP shade & $18.6^{*}$ & 3.80 & $17.0^{*}$ & 3.07 & $27.0^{\text {ns }}$ & 4.12 & $28.8^{\text {ns }}$ & 3.02 \\
SA & $19.8^{*}$ & 4.18 & $17.0^{*}$ & 2.98 & $26.4^{*}$ & 4.00 & $27.7^{*}$ & 2.60 \\
PFS & 20.2 & 4.42 & 17.4 & 3.22 & 27.1 & 4.06 & 28.8 & 2.97 \\
\hline
\end{tabular}

${ }^{1}$ Standard deviation, * significant at a level of significance of $5 \%$, ${ }^{\text {ns }}$ not significant.

Silva (2006) observed that the position of the sun changed the amount of solar radiation incident on the region near parallel $23{ }^{\circ} \mathrm{S}$, with more intense solar radiation in summer and a decrease in radiation in winter. Solar radiation is the source of energy for all terrestrial processes and the most critical meteorological element involving in regulating processes that affect other elements, including temperature, relative air humidity, wind speed, and atmospheric pressure (SOUZA et al., 2005). Changes in the amount of radiation incident on the system due to seasonality or interception of the tree component are directly associated with temperature variations between the evaluated treatments. Pezzopane et al. (2015) assessed the microclimate of a SPS and obtained similar results, with a maximum daily air temperature of $28.3{ }^{\circ} \mathrm{C}$ in the PFS and an approximate reduction of $1{ }^{\circ} \mathrm{C}$ under shade. Navarini et al. (2009) evaluated the thermal environment for beef cattle under different conditions of natural shade and found that air temperature decreased from 1.9 to $3.6^{\circ} \mathrm{C}$ under shade relative to full sun, where the maximum temperature was $30.5^{\circ} \mathrm{C}$.

There were no significant differences in the mean values of relative air humidity between the SPS and PFS (Table 2). It is of note that relative air humidity is strongly affected by temperature variations throughout the day, and it is difficult to identify differences between the SPS and PFS because wind advection can affect this variable. However, relative air humidity is inversely proportional to temperature and, as the air temperature is increased as a function of energy availability, humidity levels are decreased because of air heating (CUNHA; ESCOBEDO, 2003). For this reason, temperature measurement may allow estimating the air moisture contents of different environments. In turn, there was a slight increase in the mean values of relative air humidity in the SA in all the seasons compared with the other environments. The denser arrangement of the Leucena trees in the woodland may have favored the maintenance of the air humidity and the lower temperature in that environment.

Table 2. Relative air humidity (\%) in the silvopastoral system between tree rows (SP full sun), under tree shade (SP shade), a shaded area (SA), and pasture in full sun (PFS), in Ibiporã, state of Paraná, Brazil, in different seasons of 2017 and 2018.

\begin{tabular}{ccccc}
\hline \multirow{2}{*}{ Treatment } & Autumn & Winter & Spring & Summer \\
\cline { 2 - 5 } & $\mathbf{\%}$ & $\mathbf{\%}$ & $\mathbf{\%}$ & $\mathbf{\%}$ \\
\hline SP full sun & 84 & 74 & 57 & 69 \\
SP shade & 84 & 74 & 57 & 70 \\
SA & 87 & 77 & 60 & 75 \\
PFS & 85 & 74 & 57 & 69 \\
\hline
\end{tabular}


In autumn and winter of the year of study, the water regime was below average during most months (Figure 1), suggesting that the tree component had a crucial role in preventing humidity in the shaded systems, where the mean temperature was lower underneath the canopy. In contrast, in the PFS and SP full sun, where the effect of shade was smaller, there was higher water loss in this drier period of the year. In spring and summer, above average rainfall may have favored water storage in the soil and higher relative humidity, resulting in milder temperatures in all the studied environments. This result may justify the fact that there were no significant differences between the PFS and SPS. In the SA, dense vegetation limited heat dissipation and reduced air humidity, resulting in lower temperatures.

Figure 1. Rainfall from March 2017 to January 2018 and historical means in the city of Ibiporã, state of Paraná, Brazil.

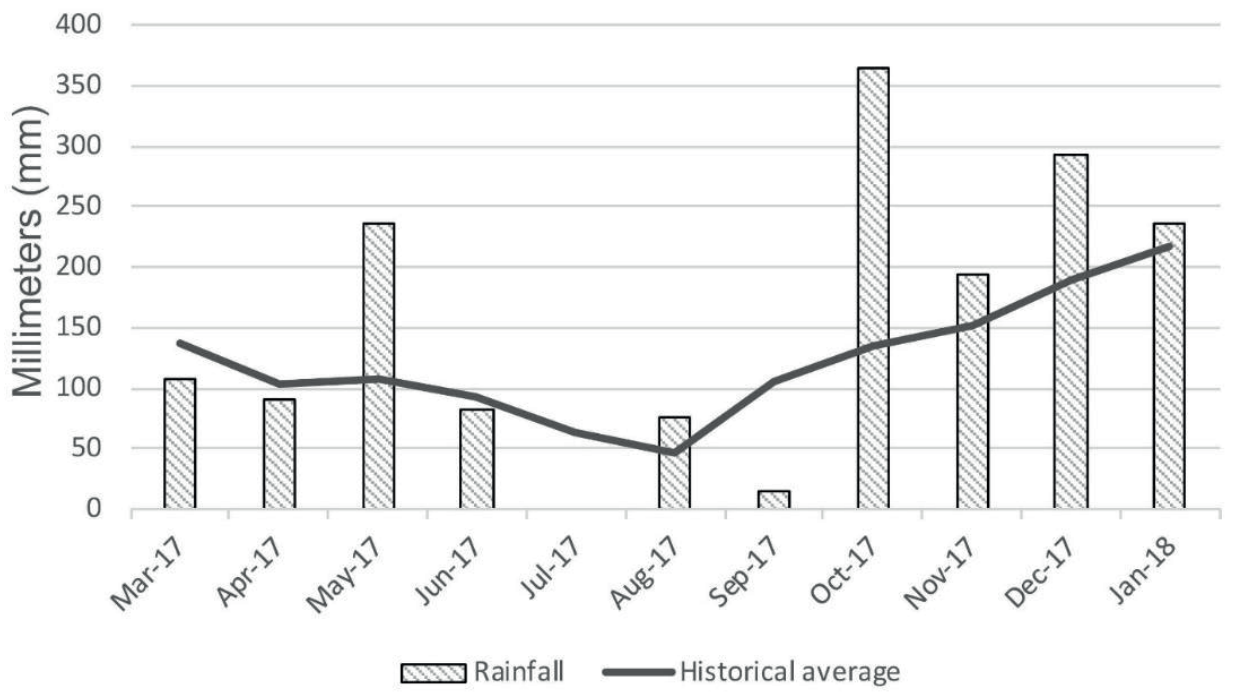

In autumn, the mean THI in the PFS was 68, and only the SP shade differed statistically from the PFS (Table 3). However, in autumn, even with the possibility of high temperatures, the climate was milder; consequently, the mean THI in all treatments represented normal conditions of thermal comfort, classified as stress threshold. The tree density in the SA may explain why THI was similar between the SA and PFS. Dense vegetation prevents heat dissipation by advection and convection in hot periods and increases temperatures. In addition, the low air moisture content due to the lower rainfall during this time of the year may have affected the THI values. Animal thermal comfort is correlated with the relative atmospheric humidity levels, which in turn are associated with temperature.
Therefore, transpiration occurs rapidly in warm and dry environments, leading to skin irritations in the animals; in contrast, warm and humid environments slow or stop transpiration, reducing thermolysis (SANTOS et al., 2005).

In winter, the mean THI was 64 , and the same pattern was observed in all shaded environments and full sun, which is within the range classified as stress threshold. In this colder season, animals usually remain few hours under high-temperature heat stress conditions. However, the tree component may play an important role in protecting animals from low-temperature stress. Similar results were found by Leme et al. (2005), whereby the THI values in a SPS in the state of Minas Gerais, southeast of Brazil, ranged from 61 to 70 in winter. 
Table 3. Comparison of the mean temperature and humidity index (THI) ( $t$-test) in the silvopastoral system between rows (SP full sun), under tree shade (SP shade), and a shaded area (SA) compared to a pasture in full sun (PFS) in Ibiporã, state of Paraná, Brazil, in different seasons of 2017 and 2018.

\begin{tabular}{ccccccccc}
\hline & \multicolumn{2}{c}{ Autumn } & \multicolumn{2}{c}{ Winter } & \multicolumn{2}{c}{ Spring } & \multicolumn{2}{c}{ Summer } \\
\hline Treatment & Mean & STD $^{1}$ & Mean & STD & Mean & STD & Mean & STD \\
\hline SP full sun & $68^{\text {ns }}$ & 5.10 & $64^{\text {ns }}$ & 3.69 & $77^{*}$ & 4.92 & $78^{\text {ns }}$ & 3.02 \\
SP shade & $66^{*}$ & 4.89 & $64^{\text {ns }}$ & 3.73 & $75^{\text {ns }}$ & 4.21 & $78^{\text {ns }}$ & 3.12 \\
SA & $68^{\text {ns }}$ & 5.09 & $64^{\text {ns }}$ & 3.65 & $74^{\text {ns }}$ & 4.12 & $76^{*}$ & 2.71 \\
PFS & 68 & 5.30 & 64 & 3.89 & 75 & 4.19 & 78 & 3.10 \\
\hline
\end{tabular}

${ }^{1}$ Standard deviation, * significant at a level of significance of $5 \%,{ }^{\text {ns }}$ not significant.

In spring, the mean THI in the SP full sun was 77, which is higher than that in the PFS (mean of 75) (Table 3). The tree lines having a north-south solar declination may have affected this result, in which the sun rays were perpendicular to the tree rows for most of the day in this season of the year. The higher incidence of solar radiation increased the temperature and THI. In general, the average thermal condition of all treatments in spring was classified as mild to moderate stress, in which animals may already suffer from thermal discomfort. Karvatte Júnior et al. (2016) analyzed three agroforestry systems with different spacing between tree rows in Campo Grande, state of Mato Grosso do Sul, Brazil, and found that the mean THI in September was 79 for the forest-livestock integration system and 83 for the full sun, and these values were higher than those found in our study in the spring in all analyzed systems.

In the summer, only the SA, with a mean THI of 76, differed from the PFS, where the mean THI was 78. However, according to the classification proposed by Zimbelman and Collier (2011), in all treatments, the animals were in mild to moderate thermal discomfort in this season. Moreover, it is of note that in December 2017 and January 2018, rainfall was high in the study region (Figure 1), which may have affected temperature and humidity values, indicating that thermal discomfort would be more severe if rainfall were within normal values. In a study conducted in the northwest of Paraná state in the summer, Navarini et al. (2009) analyzed the effect of shade of woods of guajuvira (Patagonula americana) and isolated trees of orange (Citrus sinensis) and guava (Psidium guajava), and the mean THI values were 76-78 in shaded conditions and 80 in full sun. These values are similar to those found in the present study and indicate the presence of thermal stress even in shaded environments.

The analysis of the mean THI values at three different times of the day (Figure 2) revealed that in the autumn, spring, and summer, the values were highest at 3:00 p.m. In the autumn, even at this time of the day, no environmental conditions caused thermal discomfort to the animals in any treatment. In the spring, the animals were exposed to conditions of thermal discomfort from 9:00 a.m., being classified as moderate to severe stress in treatment SP full sun at 3:00 p.m. and mild to moderate stress in other treatments and times of the day. In the summer, moderate to severe stress conditions were only observed in SP full sun at 3:00 p.m. However, high THI values (close to 80 ) were found in the SP full sun at 12:00 p.m., SP shade, and PFS at 12:00 p.m. and 3:00 p.m., which are very close to the upper limit (light to moderate stress). At 9:00 a.m., the discomfort was slightly lower but was still classified as mild to moderate stress in all treatments. Similar results were found by Gurgel et al. (2012) and Ferreira et al. (2011), wherein the THI was highest between 2:00 p.m. and 3:00 p.m. in a pasture partially shaded by dispersed native trees. 
Figure 2. Mean temperature and temperature and humidity index (THI) at different times of the day (9:00 a.m., 12:00 p.m., and 3:00 p.m.) and normal, critical, danger, and emergency thermal comfort conditions in a silvopastoral system between tree rows (SP full sun), under tree shade (SP shade), a shaded area (SA), and pasture in full sun (PFS) in Ibiporã, state of Paraná, Brazil, in different seasons of 2017 and 2018.
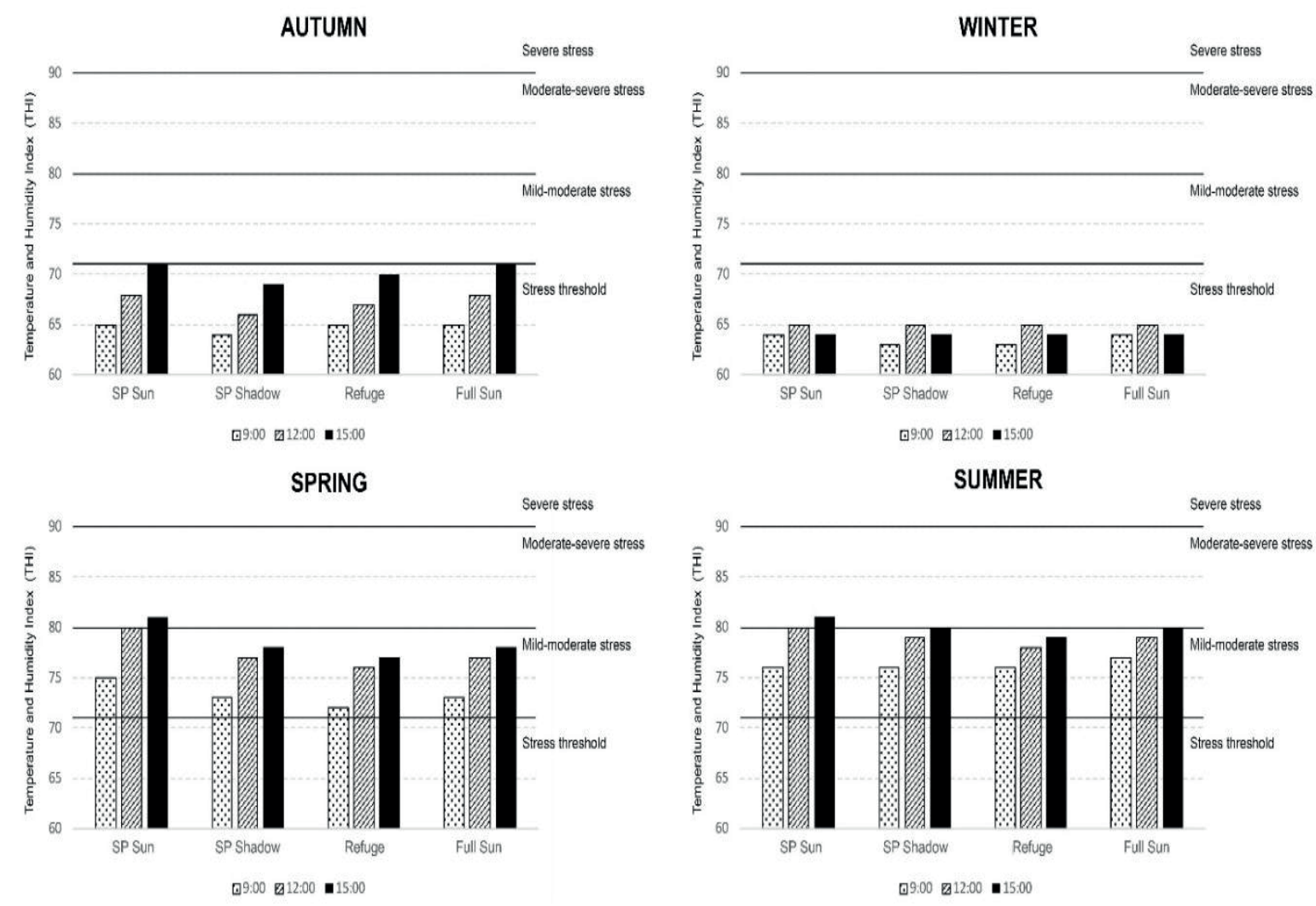

A study carried out in Campo Grande, Mato Grosso do Sul, Brazil, which is warmer than the region studied in the present study, evaluated animal thermal comfort in crop-livestock-forest integration systems with different tree spacings and found that the mean THI values in June were 75 at 9:00 a.m., 80 at 12:00 p.m., and 78 at 3:00 p.m., indicating thermal discomfort even in the coldest season of the year. The mean THI values were 81,83 , and 80 , at 9:00 a.m., 12:00 p.m., and 3:00 p.m., respectively, in August, and 85, 86, and 84, at 9:00 p.m., 12:00 p.m., and 3:00 p.m., respectively, in September. In the last two months of the study, thermal discomfort was moderate to severe (KARVATTE JÚNIOR et al., 2016).

Corroborating with the results of Baêta and Souza (2010) and Karvatte Júnior et al. (2016) regarding the thermal comfort in shaded systems, none of the systems examined in the present study provided thermal stress-free conditions throughout the day and at different periods of the year. However, the arboreal component has a fundamental role because shade changed the radiation balance of the animals, protecting them against direct solar radiation, although the air temperature and humidity remained unchanged (BARBOSA et al., 2004). In this respect, Martello et al. (2004) observed no changes in the thermoregulation of Dutch cows even in high daily THI (76), and Matarazzo et al. (2007) found thermal stress conditions in Dutch cows even in environments with a THI of 75 .

The estimation of thermal comfort using the THI does not consider the effect of winds on the systems. This meteorological element plays a vital 
role in the lateral transport of heat by advection. This process was much more efficient in the PFS, and therefore, the THI did not correspond to real field conditions. Another important element was the solar radiation incident on the animals, which directly affected body temperature. In this respect, the body temperature of the animals should be monitored to accurately estimate thermal comfort by changes in metabolism, as reported by Perissinotto and Moura (2007) and Matarazzo et al. (2007), who determined thermal comfort in Dutch cows by monitoring their rectal temperature and respiratory rate.

The behavior of animals is also highly influenced by environmental conditions, and thermal discomfort may change eating habits and reduce the productive potential. The animal ingestion behavior from 8:00 a.m. to 5:00 p.m. in three days of analysis in different seasons is shown in Figure 3. In general, a typical behavior was usually observed in all evaluated days, with grazing in early morning and late afternoon. Such behavior was also observed by Ribeiro et al. (2012), in which the animals grazed throughout the day, and this activity was reduced in the warmer periods of the day. Rumination or idleness was concentrated in the warmer periods, and this strategy helped save energy. After feeding in a specific region of the pasture, the animals started grazing in a new area.

In the northern region of Paraná, where the present study was conducted, the animals are subject to thermal discomfort due to high temperatures in the fall. Therefore, in the analysis performed in $04 / 19 / 17$, the animals preferred grazing in periods of milder temperature, and rumination and idleness were concentrated in the hottest period of the day, from 11:00 a.m. to 4:00 p.m. (Figure 3). Moreover, the animals remained under tree shade most of the day. In the analyzed day, the mean temperature varied from $20^{\circ} \mathrm{C}$ to $27^{\circ} \mathrm{C}$, demonstrating that the animals were searching for the thermal comfort provided by tree shade. Furthermore, more than $80 \%$ of the animals were under shade from 11:30 a.m. to $3: 30$ p.m.

Similar behavior was observed in 23/06/17. However, the search for shade was lower because of the milder temperatures in the winter. The animals sought shade only after 12:00 p.m. and no longer sought shade after 2:30 p.m. when the temperature began to decrease. Therefore, grazing was concentrated in the morning, until 11:00 a.m., and in the late afternoon, after 3:00 p.m.. Rumination occurred predominantly in the warmer period of the day, from 11:00 a.m. to 3:00 p.m., when the animals sought shade. The results of Penning et al. (1991), Brâncio et al. (2003), and Bremm et al. (2008) were similar to those of this study in autumn and winter, where the grazing period ranged from 6.8 to 11.3 hours, and this activity was performed preferentially during the day. These authors observed that most of the grazing occurred approximately 4 hours before sunset, from 2:00 p.m. to 5:00 p.m., and early in the morning, when temperatures were milder.

Temperatures are high in northern Paraná in the spring. On $12 / 12 / 17$, the mean air temperature ranged from $21{ }^{\circ} \mathrm{C}$ to $30{ }^{\circ} \mathrm{C}$, and the animals sought shade since early morning, with $70 \%$ of the animals being under shade most of the day. The animals alternated between grazing and rumination activities throughout the day, and did not perform the same activity in a specific period of the day. Costa et al. (2015) observed that the intake of forage was higher during the day in the wetter period of the year compared with the driest period. The animals searched for food sources during the day to supply their nutritional needs and ruminated in the evening. The presence of trees facilitated grazing for several hours of the day, guaranteeing greater thermal comfort. Shade affects animal behavior by favoring grazing, improving animal productivity (PASTAL et al., 2015). 
Figure 3. Animal ingestive behavior in a shaded area and an area in full sun in a silvopastoral system from 8:00 a.m. to 5:00 p.m. in Ibiporã, state of Paraná, Brazil, 2017.

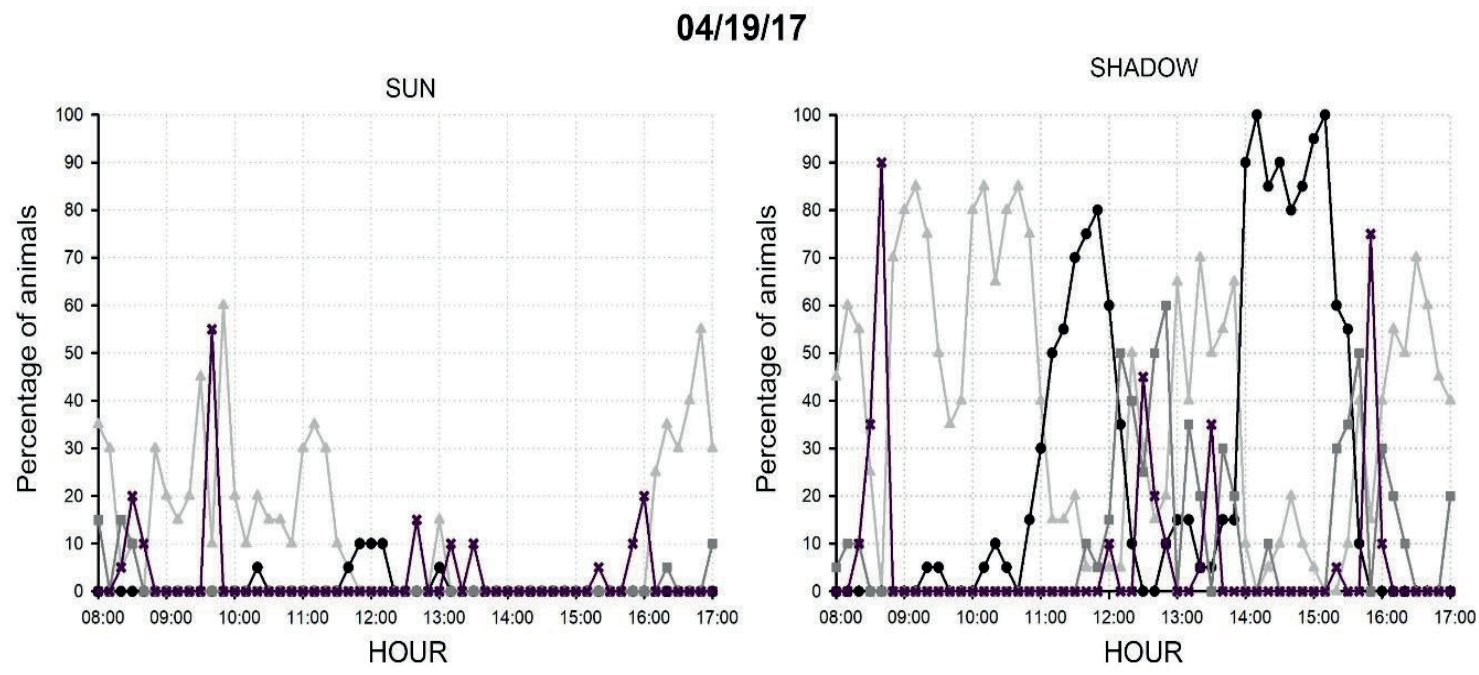

$06 / 23 / 17$
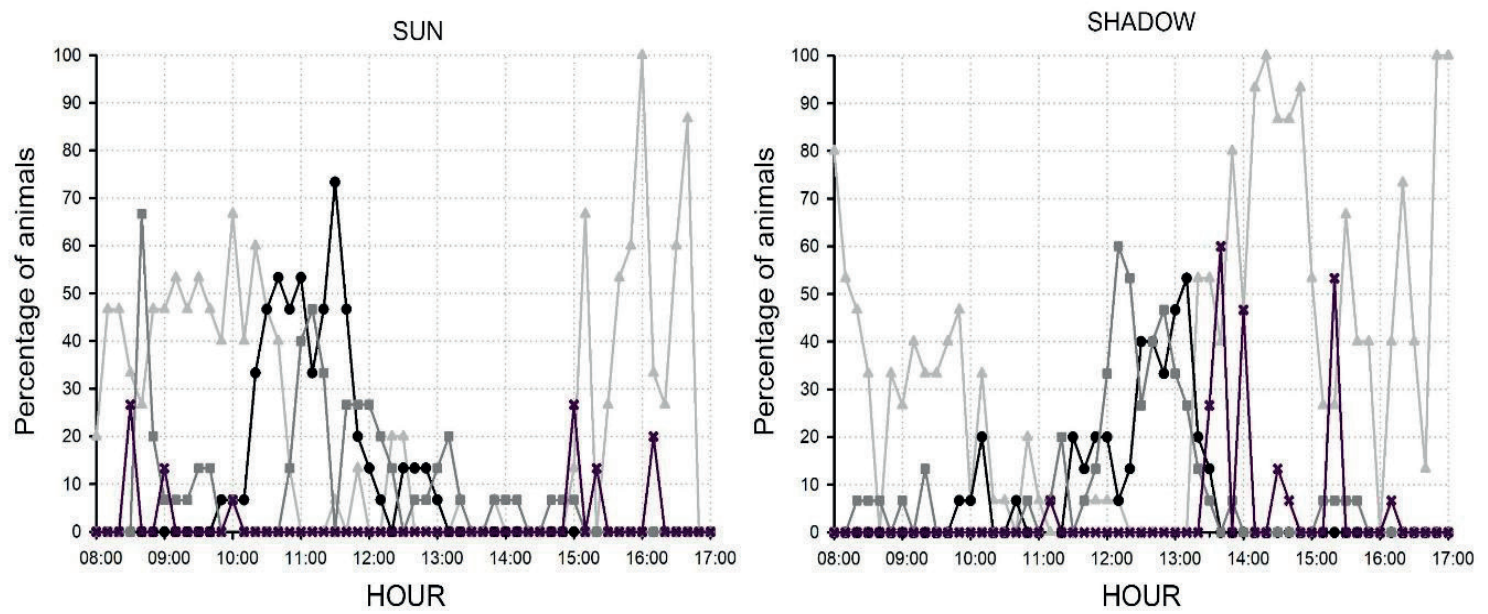

$12 / 12 / 17$
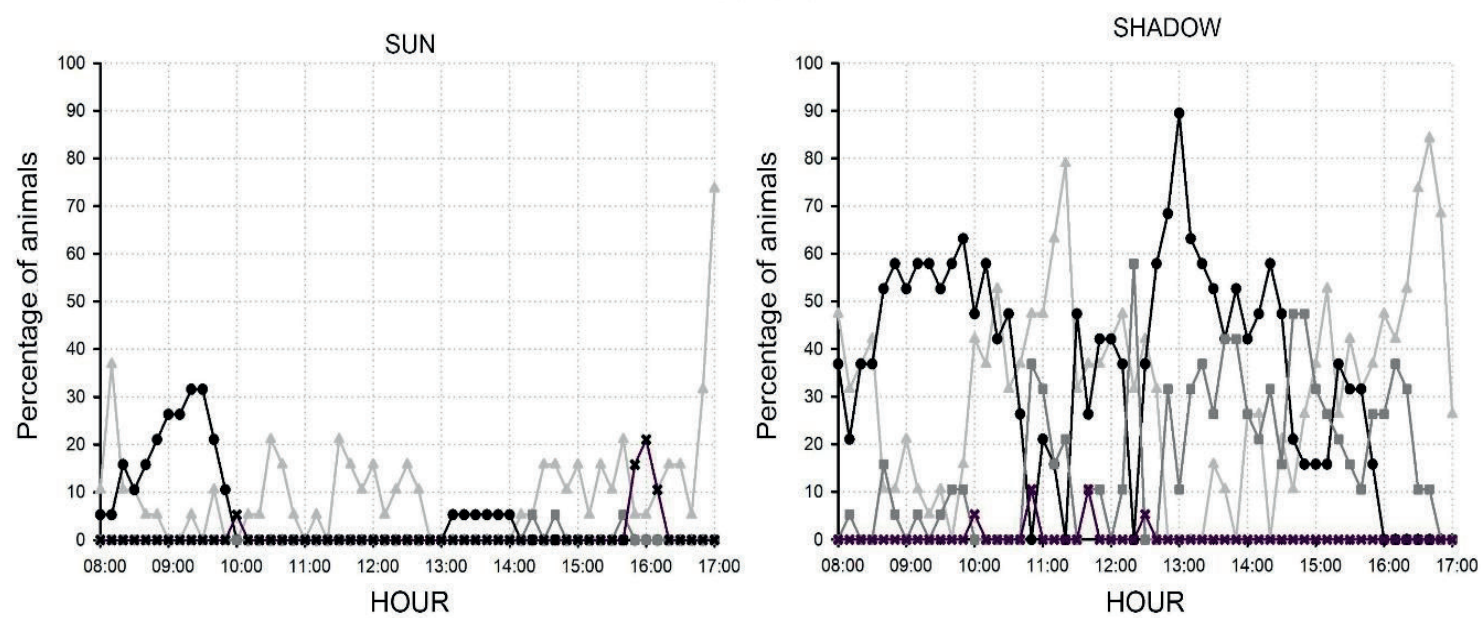

$\longrightarrow$ GRAZING $\rightarrow$ RUMINATION $\rightarrow$ IDLENESS $\rightarrow$ DISPLACEMENT 


\section{Conclusions}

The tree component directly affected the microclimate of shaded systems both in the SPS and SA. In general, there was a reduction in air temperature in relation to grazing area in full sun. The tree shade had an important role in protecting the animals against direct solar radiation, providing greater thermal comfort, and facilitating grazing in the hottest times of the day.

The SPS and SA provided better thermal conditions in autumn and summer, respectively, with a reduction of the THI compared with the PFS. However, in all the studied environments, conditions of thermal discomfort for Dutch cows were observed in the spring and summer, and the latter presented the highest THI values.

The animals sought tree shade in the hottest hours of the day, especially in spring and summer, indicating the importance of natural shading to improve thermal comfort.

\section{References}

BAÊTA, F. C.; SOUZA, C. F. Ambiência em edificações rurais: conforto animal. 2. ed. Viçosa, MG: Editora UFV, 2010. 269 p.

BARBOSA, O. R.; BOZA, P. R.; SANTOS, G. T.; SAKAGUSHI, E. S.; RIBAS, N. P. Efeitos da sombra e da aspersão de água na produção de leite de vacas da raça Holandesa durante o verão. Acta Scientiarum. Animal Sciences, Maringá, v. 26, n. 1, p. 115-122, 2004.

BRÂNCIO, P. A.; EUCLIDES, V. P. B.; NASCIMENTO JÚNIOR, D.; FONSECA, D. M.; ALMEIDA, G.; MACEDO, M. C. M.; BARBOSA, R. A. Avaliação de três cultivares de Panicum maximum Jacq. sob pastejo: comportamento ingestivo de bovinos. Revista Brasileira de Zootecnia, Viçosa, MG, v. 32, n. 5, p. 1045-1046, 2003.

BREMM, C.; ROCHA, M. G.; FREITAS, F. K.; MACARI, S.; ELEJALDE, D. A. G.; ROSO, D. Comportamento ingestivo de novilhas de corte submetidas a estratégias de suplementação em pastagens de aveia e azevém. Revista Brasileira de Zootecnia, Viçosa, MG, v. 37, n. 7, p. 11611167, 2008.

\section{COMISSÃO ECONÔMICA PARA A AMÉRICA}

LATINA E CARIBE - CEPAL; FOOD AND AGRICULTURE ORGANIZATION - FAO; INSTITUTO INTERAMERICANO DE COOPERAÇÃO PARA AGRICULTURA - IICA. Perspectivas de la agricultura y del desarrollo rural en las Américas: una mirada hacia América Latina y el Caribe. San José: IICA, 2017. 257 p.

COSTA, J. V.; OLIVEIRA, M. E.; MOURA, R. M. A.; COSTA JÚNIOR, M. J. N.; RODRIGUES, M. M. Comportamento em pastejo e ingestivo de caprinos em sistema silvipastoril. Revista Ciência Agronômica, Fortaleza, v. 46, n. 4, p. 865-872, 2015.

CRUZ, L. V.; ANGRIMANI, D. S. R.; RUI, B. R.; SILVA, M. A. Efeitos do estresse térmico na produção leiteira: revisão de literatura. Revista Científica Eletrônica de Medicina Veterinária, Garça, v. 16, n. 6, p. 1-18, 2011.

CUNHA, A. R.; ESCOBEDO, J. F. Alterações micrometeorológicas causadas pela estufa plástica e seus efeitos no crescimento e produção da cultura de pimentão. Revista Brasileira de Agrometeorologia, Santa Maria, v. 11, n. 1, p. 15-27, 2003.

DOMICIANO, L. F.; MOMBACH, M. A.; CARVALHO, P.; SILVA, M. N. F.; PEREIRA, D. H.; CABRAL, L. S.; PEDREIRA, B. C. Performance and behaviour of Nellore steers on integrated systems. Animal Production Science, Clayton South, v. 58, n. 10, p. 920-929, 2016.

EMPRESA BRASILEIRA DE PESQUISA AGROPECUÁRIA - EMBRAPA. Sistema brasileiro de classificação de solos. Brasília: Embrapa Informação Tecnológica, 2013. 342 p.

FOOD AND AGRICULTURE ORGANIZATION FAO. OECDFAO Agricultural outlook 20162025 special focus: SubSaharan Africa, Paris: OECD/FAO, 2016.

. Review of evidence on drylands pastoral systems and climate change: implications and opportunities for mitigation and adaptation. Roma: Land and Water Division, 2010.

FERREIRA, L. C. B.; MACHADO FILHO, L. C. P.; HOETZEL, M. J.; LABARRÊRE, J. G. O efeito de diferentes disponibilidades de sombreamento na dispersão de fezes dos bovinos nas pastagens. Revista Brasileira de Agroecologia, Cruz Alta, v. 6, n. 1, p. 137146, 2011.

FREITAS, C. A.; GOULART, D. D.; ALVES, F. D. O processo de arenização no Sudoeste do Rio Grande do Sul: uma alternativa para seu desenvolvimento sócioeconômico. Santa Maria: Departamento de Ciências Econômicas da Universidade Federal de Santa Maria (UFSM), 2011. Disponível em: <http://cdn.fee.tche.br/ eeg/1/mesa_11_freitas_goulart_alves.pdf $>$. Acessado em: 15 jun. 2018 . 
GUEDES, A. L. Uma plataforma de hardware e software para desenvolvimento de rede de sensores sem fio aplicada a agrometeorologia. 2013. Dissertação (Mestrado em Engenharia Elétrica) - Universidade Estadual de Londrina, Departamento de Engenharia Elétrica, Londrina.

GURGEL, E. M.; SERAPHIM, O. J.; SILVA, I. J. O. Método de avaliação bioclimática da qualidade da sombra de árvores visando ao conforto térmico animal. Revista de Engenharia Agrícola, Botucatu, v. 27, n. 2, p. 20-34, 2012.

INSTITUTO AGRÔNOMICO DO PARANÁ - IAPAR. Zoneamento Agrícola do Estado do Paraná. Londrina: IAPAR, 2009. 76 p.

INSTITUTO BRASILEIRO DE GEOGRAFIA E ESTATÍSTICA - IBGE. Pesquisa pecuária municipal (1974-2010). Rio de Janeiro: Pec. Munic., 2010. Disponível em: <http://www.sidra.ibge.gov.br/bda/ tabela/ listabl.asp? $\mathrm{z}=\mathrm{t} \& \mathrm{o}=24 \& \mathrm{i}=\mathrm{P} \& \mathrm{c}=73>$. Acesso em: 15 jun. 2018.

Pesquisa pecuária municipal. Rio de Janeiro: Pec. Munic., 2016. Disponível em: http: <www.ibge. gov.br>. Acesso em: 15 jun. 2018.

JANK, L.; BARRIOS, S. C.; VALLE, C. B.; SIMEÃO, R. M.; ALVES, G. F. The value of improved pastures to Brazilian beef production. Crop and Pasture Science, Clayton South, v. 65, n. 11, p. 1132-1137, 2014.

JAMIESON, W. S.; HODGSON, J. The effect of variation in sward characteristics upon the ingestive behavior and herbage intake of calves and lambs under continuous stocking management. Grass and Forage Science, Hurley, v. 34, n. 4, p. 273-281, 1979.

KARVATTE JÚNIOR, N.; ALVES, F. V.; KLOSOWSKI, E. S.; ALMEIDA, R. G.; TSUTSUMI, C. Y.; OLIVEIRA, C. C. Microclima e índices de conforto térmico em sistemas de integração lavoura-pecuária-floresta no munícipio de Campo Grande, MS. 21. ed. Brasília: EMBRAPA Gado de Corte, 2016. 38 p.

LEME, T. M. S. P.; PIRES, M. F. A.; VERNEQUE, R. S.; ALVIM, M. J.; AROEIRA, L. J. M. Comportamento de vacas mestiças Holandês-Zebu, em pastagem de Brachiaria decumbens em sistema silvipastoril. Ciência e Agrotecnologia, Lavras, v. 29, n. 3, p. 668-675, 2005.

MARTELLO, L. S.; SAVASTANO JÚNIOR, H.; SILVA, S. L.; TITTO, E. A. L. Respostas fisiológicas e produtivas de vacas holandesas em lactação submetidas a diferentes ambientes. Revista Brasileira de Zootecnia, Viçosa, MG, v. 33, n. 1, p. 181-191, 2004.

MATARAZZO, S. V.; SILVA, I. J. O.; PERISSINOTTO, M.; MOURA, D. J.; FERNANDES, S. A. A.; ARCARO
JÚNIOR, I.; ARCARO, J. R. P. Eficiência de sistemas de climatização na área de descanso em instalações do tipo freestall e sua influência nas respostas produtivas e fisiológicas de vacas em lactação. Boletim de Indústria Animal, Nova Odessa, v. 64, n. 3, p. 221-232, 2007.

MOURA, D. J.; BUENO, L. G. F.; LIMA, K. O.; CARVALHO, T. M. R.; MAIA, A. P. A. Strategies and facilities in order to improve animal welfare. Revista Brasileira de Zootecnia, Viçosa, MG, v. 39, p. 311-316, 2010. Suplemento Especial.

NAVARINI, F. C.; KLOSOWSKI, E. S.; CAMPOS, A. T.; TEIXEIRA, R. A.; ALMEIDA, C. Conforto térmico de bovinos da raça nelore a pasto sob diferentes condições de sombreamento e a pleno sol. Engenharia Agrícola, Jaboticabal, v. 29, n. 4, p. 508-517, 2009.

PASTAL, D.; CRISTO, A. B.; FUJISAWA, F. M.; MAIER, G. S.; GUIRRO, E. C. B. P. Papel do sombreamento no conforto térmico de vacas leiteiras criadas a pasto revisão de literatura. Veterinária em Foco, Canoas, v. 12, n. 2, p. 92-100, 2015.

PENNING, P. D.; PARSONS, A. J.; ORR, R. J.; TEACHER, T. T. Intake and behaviour responses by sheep to changes in sward characteristics under continuous stocking. Grass and Forage Science, Hurley, v. 46, n. 1, p. 15-28, 1991.

PERISSINOTTO, M.; MOURA, D. J. Determinação do conforto térmico de vacas leiteiras utilizando a mineração de dados. Revista Brasileira de Engenharia de Biossistemas, Campinas, v. 1, n. 2, p. 117-126, 2007.

PEZZOPANE, J. R. M.; BOSI, C.; NICODEMO, M. L. F.; SANTOS, P. M.; CRUZ, P. G.; PARMEJIANI, R. S. Microclimate and soil moisture in a silvipastoral system in southeas tern Brazil. Bragantia, Campinas, v. 74, n. 1, p. 110-119, 2015.

RIBEIRO, A. M.; OLIVEIRA, M. E.; SILVA, P. C.; RUFINO, M. O. A.; RODRIGUES, M. M.; SANTOS, M. S. Canopy characteristics, animal behavior and forage intake by goats grazing on Tanzaniagrass pasture with different heights. Acta Scientiarum. Animal Sciences, Maringá, v. 34, n. 4, p. 371-378, 2012.

SANTOS, F. C. B.; SOUZA, B. B.; ALFARO, C. E. P.; CÉSAR, M. F.; PIMENTA FILHO, E. C.; ACOSTA, A. A. A.; SANTOS, J. R. S. Adaptabilidade de caprinos exóticos e naturalizados ao clima semi-árido do nordeste brasileiro. Ciência e Agrotecnologia, Lavras, v. 29, n. 1, p. 142-149, 2005.

SILVA, R. G. Predição da configuração de sombras de arvores em pastagens para bovinos. Engenharia Agrícola, Jaboticabal, v. 26, n. 1, p. 268-281, 2006.

SOUZA, J. L.; NICÁCIO, R. M.; MOURA, M. A. L. 
Global solar radiation measurements in Maceió, Brazil. Renewable Energy, Brighton, v. 30, n. 8, p. 1203-1220, 2005.

SOUZA, W.; BARBOSA, O. R.; MARQUES, J. A.; COSTA, M. A. T.; GASPARINO, E.; LIMBERGER, E. Microclimate in silvipastoral systems with eucalyptus in rank with different heights. Revista Brasileira de Zootecnia, Viçosa, MG, v. 39, n. 3, p. 685-694, 2010.

STRASSBURG, B. B. N.; LATAWIEC, A. E.; BARIONNI, L. G.; NOBRE, C. A.; SILVA, V. P.; VALENTIM, J. F.; VIANNA, M.; ASSAD, E. D. When enough should be enough: improving the use of current agricultural lands could meet production demands and spare natural habitats in Brazil. Global Environmental Change, Victoria, v. 28, n. 1, p. 84-97, 2014.

UNITED NATIONS. Probabilistic population projections based on the world population prospects: the 2012 revision. ST/ESA/SER.A/353. New York: ESA/P/ WP, 2014. Available at: <https://esa.un.org/unpd/wpp/ publications/Files/WPP2012_HIGHLIGHTS.pdf>. Accessed at: 17 jun. 2018.

ZIMBELMAN, B. R.; COLLIER, R. J. Feeding strategies for high producing dairy cows during periods of elevated heat and humidity. In: TRI-STATE DAIRY NUTRITION CONFERENCE, 2011, Tempe. Proceedings... Tempe: [s.n.], 2011. p. 111-126. 
